\title{
Re-Discovering Brazilian Literary History: The Case for Translation
}

\author{
MARTÍN GASPAR
}

Bryn Mawr College

\begin{abstract}
This article proposes translation as an alternative framework to Brazilian literary history. First, it offers a rereading of Pêro Vaz de Caminha's Carta do achamento as a text that narrates attempts at intercultural communication through scenes that stage different attitudes and politics towards translation. Then, it traces the recurring presence of these attitudes (labeled "translation regimes") in major literary events in Brazilian literature. In particular, it focuses on twenty-first century fictions by João Gilberto Noll and Chico Buarque that, like Caminha's text, narrate encounters with unknown languages as intimate episodes that affect individuals' bodies and identities. Through this example, I show how translation enables finding diachronic affinities and unexpectedly recurrent obsessions in Brazilian literary history.
\end{abstract}

Keywords: Brazilian literary history, Carta do achamento, translation, contemporary fiction, historiography

If Pêro Vaz de Caminha's Carta do achamento is the "birth certificate" of Brazilian literature, then Brazilian letters were born with a reflection on the problem of translation. ${ }^{1}$ Read and re-read, this seminal text has been described in myriad ways. For Lisa Voigt, it is a fiction of intermingling, while for Keith

\footnotetext{
${ }^{1}$ According to Carneiro, Capistrano de Abreu was the first to refer to the Carta as a "birth certificate" (105).
} 
Louis Walker it is primarily an ethnographic text. Wilson Martins considers Caminha's letter a prelude to the persistent Brazilian concern with describing landscapes, pointing out that it "initiates among us the literature of the knowledge of the land" and therefore "seems to have been the prelude to every written text in Brazil" (233). For Jerry Williams, the letter reflects the changing dimensions of the Renaissance's literary and cognitive efforts to chronicle the New World and offers valuable insights into the budding humanistic frankness with which Brazil was first viewed. José Aderaldo Castello sees it as a source for modernist experimentation, while Erico Veríssimo reads it as a harbinger of the pernicious discourse of abundance that has run through Brazilian history since the sixteenth century. Yet what haunts Caminha's letter at every step, what seemingly obsesses the escrivão, is a somewhat forgotten preoccupation: narrating attempts atpresent and future, imagined, real and potential —intercultural communication. And it does so insistently, through a series of scenes that stage different attitudes and even politics regarding translation.

The fact that translation figures prominently in a foundational text that is said to contain kernels of future literary tendencies entices one to re-visit Brazilian literary history from a perspective that is particularly relevant in our time. In fact, if writing a literary history involves a dialectic of past and present - it starts form matters that we consider significant now and it is from our hermeneutic position that we ascribe importance to past events - it is hard to imagine a better protagonist for Brazilian literary history than translation today, when the anxieties of interconnectedness are so pressing (more so than the age-old struggles to define a national or Latin American identity that have so often given shape to our literary histories.) What, then, would a literary history constructed around translation help us see? In what ways can a dialectic of past and present allow us to make Caminha's Carta relevant to us now, on the basis of its (and our) interest in translation? And, conversely, does current literature that engages the question of translation cast a new light on the foundational document?

In the following pages I will explore these questions in four steps. First, I will examine Caminha's text to identify attitudes toward translation in it that I shall call translation regimes. Then, I will demonstrate the productivity of this approach by tracing some literary events in which translation operates in analogous fashion in Brazilian letters in the nineteenth and twentieth centuries. I will then focus on recent fiction: I will pinpoint scenes of encounter with 
unknown cultures and languages that, first seen in the Carta do achamento during the first wave of globalization, reappear in contemporary Brazilian novels. I will claim that considering Caminha's letter and contemporary novels as participating in the same translation regime helps us identify illuminating affinities. Finally, I will argue that classifying texts according to transhistorical categories like translation regimes - instead of placing them along the usual narratives of progress and continuity - ultimately expands our sense of history and our capacity to situate literary events as both singular episodes and participants in a tradition.

\section{Caminha's Carta and the Problem of Translation}

At the beginning of his letter to the King, Caminha writes that as the ships were getting close to the shores they saw native inhabitants with hunting bows. A soldier, Nicolau Coelho, made a sign to them to put down their bows, and they did. But at that moment, any kind of conversation became impossible:

[...] aly nom pode deles auer fala ne[m] ente[n]dimento que aproueitasse polo mar quebrar na costa. soomente deulhes huu[m] barete vermelho e huu[m]a carapuça de linho que leuaua na cabeça e huu[m] sombreiro preto. $\mathrm{E}$ huu[m] deles lhe deu huum sombreiro de penas daues compridas cõ huu[m]a copezinha pequena de penas vermelhas epardas coma de papagayo e outro the deu huu[m] rramal grande de comtinhas brancas meudas que querem pareçer daljaueira as quaaes peças creo queo capitam manda avossa alteza e com jsto se volueo aas naaos por seer tarde e nom poder deles auer mais fala por aazo do mar. (f. $1^{\mathrm{v}}$ )

Verbal communication is precluded not by language difference but by the noisy setting there and then. Later in the letter, the one factor that impedes dialogue is not the encounter of mutually unknown languages but, according to Caminha, the alien screams of the natives: "aly por emtam nom ouue mais fala ne[m] emtendimento cõ eles por aberberja deles seer ta manha que se nom emtendia nem ouuja njnge[m]" (f. $4^{1}$ ). The implication in these two instances is that if were not for the natives' barbaric speech and the sound of the waves, Coelho and 
the soldiers could have communicated with the Tupinamba. The possibility of translation or interpretation does not yet, however, enter the picture.

Up to this point, Caminha's account expresses lack of communication as a problem with oral interaction and its materiality in general, not any language in particular - that is, a problem with distinguishing noises from phonemes. What has been established in these two moments of the letter is the aly/there: the very encounter with the Other on a common ground, or common shore. In this instance of material contact and exchange (caps and hats change hands; objects enter into a dialogue), it is impossible to recognize the contours of language. This is the interpretive regime, ${ }^{2}$ which arises when the question of meaning first emerges and precedes interlinguistic and intercultural translation because the distinction between nature's noises and human voices, and between talking and groaning, is not evident.

The second regime, which I call projective, appears when the natives are invited to meet with the Captain, who is properly attired for the performance of encounter. The visit of the Tupinamba to the ship is, Francisco Ortega explains, "carefully staged to exact submission and obedience" and to yield information concerning goldmines (27). But something does not quite work out as expected: "the two young men taken to the main ship," Ortega continues, "do not recognize European power arrangements of ceremonial procedures." Under these crafted circumstances and looming failure, Caminha writes that one of the natives "pos olho no colar do capitam e começou daçenar cõ amaão peraaterra e depois perao colar como que nos dezia que avia em tera ouro" (f. $3^{\text {r }}$ ). In this moment of the account, the deictic has shifted: it no longer points to the common shore (the aly/there of encounter) but, rather, projects over to the country - the land signaled "over there" that deserves conquering. It is rather curious that a single gesture would mean something so specific, and Caminha is aware that much of his interpretation is indeed a projection of his own desires. At some point, his translations become so tendentious that he comes to admit to the King-perhaps to confide in him, considering that, according to Cortesão, Caminha is a "cidadão

\footnotetext{
${ }^{2}$ This term is inspired by Gadamer's understanding of interpretation as a practically oriented mode of insight. For Gadamer, who defines understanding through a topological metaphor, as a process of the "fusion of horizons," situatedness is key. The interpretive regime takes hold when the question of meaning comes about, when there is a spatial coincidence or clash of horizons and cultures.
} 
do Porto" who speaks to the King with a particular sense of camaraderie- that they are indeed a product of his, and the fleet's, own wishes:

Vio huu[m] deles huu[m]as contas de rrosairo brancas. açenou que lhas desem e folgou muito com elas e lancouas ao pescoço e despois tirouas e enbrulhouas no braço e acenaua peraa trra e entã peraas contas eperao colar do capitam como que dariam ouro por aquilo. Isto tomauamonos asy polo de sejarmos mas se ele queria dizer que leuaria as contas e mais ocolar. jsto nom querjamonos emtender porque lho nõ aviamos de dar. (f. $3^{\text {r) }}$

In the projective regime the translator puts words in the Other's mouth - through strategic "as ifs" ("como que nos dezia"). The deictics, like arrows, are now launched over to the land to be exploited. The words and gestures of the Other, incomprehensible in the interpretive regime, get domesticated by the translator's desires in the projective: "Isto tomauamonos asy polo de sejarmos."

The third translation regime in Caminha's letter, which I call extractive, involves conquering souls. Caminha foresees the potential for mass conversion of the natives, which he puts in a low-effort/high-reward, mercantile terms: "e ele que nos per aquy trouue creo que nom foy sem causa e por tanto Vosa alteza pois tamto deseja acreçentar na santa fe catolica. deue emtender em sua saluaçam e prazera ads que com pouco trabalho sera asy" (f. $11^{\mathrm{v}}$ ). For conversion to happen, brokers that can extract information about the land and the local culture are necessary. The degradados are destined for the job:

Per onde pareçeo atodos que nhuu[m]a jdolatria ne[m] adoraçom teem. Ebem creo que se vosa alteza aquy mandar quem mais antreles de vagar ande. que todos seram tornados ao desejo de vosa alteza. e pera jsso se alguem vjer nõ leixe logo de vijr clerjgo peraos bautizar por que ja emtã teerã mais conhecime[n]to de nossa fe pelos dous degradados que aquy ã treles ficam os quaes ambos oje tam bem comungaram. (f. $13^{\mathrm{r}}$ )

One notices the shift in deixis. If in the interpretive regime, the aly/there points to the common area of confusion, and in the projective regime the aly/there points to the prospective area to be materially conquered and exploited, in the extractive 
regime there is an aquy/here: "aquy ã treles ficam." This here points to the land that has been appropriated and from which resources (in this case, souls) will be extracted with the adequate technologies (in the logic of this sentence, evangelization coupled with translation.) This is the here of the cross and the first mass, (trans)planted on firm land.

These are, then, three regimes of translation in Caminha's text: interpretive, projective, and extractive. I call them "regimes" because these are operations that carry certain politics, attitudes, but are not paradigms in the Kuhnian sensethere is not necessarily a "shift" in which one regime ends and another one begins. Regimes do not construct a narrative, nor signal a progression or "progress." However, they do appear and disappear under particular circumstances. The interpretive regime accompanies moments when neither meaning nor power have been established firmly in the contact zone. In the projective, the translated culture is represented and spoken for. In the extractive, it is deemed teachable and exploitable.

According to a literary history centered on translation, these three regimesof which there may be others - will reappear in Brazilian letters under other circumstances. Let us look first at what I consider to be some examples of projective and extractive translations to illustrate how thinking in terms of regimes can yield fruitful and unexpected diachronic comparisons. We will find them playing a prominent role during most of Brazilian history, especially in the nineteenth and twentieth centuries. Later on I will discuss the interpretive regime, with its baffling encounters, which takes center stage in the twenty-first century.

\section{Projective and Extractive Translations in Literary History}

In mid-nineteenth-century Brazil (and Latin America in general), there is a general anxiety to define the nation and delineate a national character. The problem is that the model for such definitions (and, one should say, the model for such anxiety) is also foreign. How can a literature remain in dialogue with Europe (and "civilization") and follow European ideals without becoming what Gilberto Freyre called "sub-European" (123)? Projective translations of the native language and culture provided an answer to this question to a major literary figure: José de Alencar. In a letter to Dr. Domingos José Nogueira Jaguaribe, he explains: 
Sem dúvida o poeta brasileiro tem de traduzir em sua língua as idéias, embora rudes e grosseiras, dos índios; mas nessa tradução está a grande dificuldade; é preciso que a língua civilizada se molde quanto possa à singeleza primitiva da língua bárbara; e não represente as imagens e pensamentos indígenas senão por termos e frases que ao leitor pareçam naturais na boca do selvagem. (312)

In this way, Alencar claims novels like his Iracema: lenda do Ceará (1865) as an exemplary translation while anointing himself as the Brazilian writer. The national novelist must study the savage life of the natives and their barbaric language and then translate them, while carefully avoiding painting them with the veneer of foreign ideals of civilization. ${ }^{3}$

Yet Alencar translates what he expects the "crude and coarse" native ideas to be. There is no original "Tupi" of this novel, and the glossary appended to it is, according to experts, dubious at best. Federico G. Edelweiss, for example, claims that Alencar's 'etymological references prove that he either didn't know or didn't learn from [Anchieta's nor Figueira's grammars] the most basic lessons," and goes as far as to impugn the very name of the novel and its protagonist: "It would suffice Alencar's definition [of "Iracema" as "honey lips"] to make it abundantly clear that Alencar had very limited knowledge of tupi, that he even confuses with guaraní [...] Honey Lips would be translated in línguageral as ira rembé, but no tupi native would use such a cacophonic composite; instead, they would use the legitimate and euphonic eirembé" $(12,26,27)$. The Tupi origin of the novel is, thus, a fiction that, as the author points out to Jaguaribe, tries to strike the reader as natural. The novel is written "as if" the Indians had a certain style, "as if" the text were a legend of Ceará (aly/over there in the "true" Brazilian hinterland.) The appropriative quality of this translation is

\footnotetext{
${ }^{3}$ This is a mistake that Alencar observes in Os Timbiras, a creation by Gonçalves Dias who, despite knowing the language and culture of the indigenous community, presented them without "certa rudez ingênua de pensamento e expressão," and made them speak instead in "uma linguagem classica" (qtd. in A polêmica 54). To this, Alencar opposes "[um] estylo poético e figurado, próprio das raças incultas" (313). For Alencar, this style should not only be present in the dialogues but also in the narration itself, in songs and rituals, in analogies inspired by local flora and fauna, in detailed descriptions of the landscape, and even in etymological explorations of the native Tupi language. The first edition of Iracema includes a glossary that clarifies terminology and idioms as if the text were indeed a translation.
} 
clear: onto the tupi language and tradition, Alencar projects his need for a national literature according to foreign ideals and expectations.

If Alencar fashioned himself as a translator of the Tupi language and culture in the nineteenth century in order to produce a national novel, other writers and intellectuals followed a positivistic drive that was almost diametrically opposed to the novelist's Romantic valorization (and construction) of native simplicity. Extractive translations were, to these apostles of progress, key. A prime case is José B. Monteiro Lobato, by far the most powerful figure in the book industry in Brazil in the first half of the twentieth century, who sought to rebuild a nation by inculcating new values to generations of young Brazilians through his translations. As John Milton has put it, Monteiro Lobato "used his adaptations of children's literature in order to insert many of his political, economic, and educational ideas," ideas that opposed the nationalist economic policies of Getúlio Vargas (211). Lobato wanted to educate here with the tools from abroad, to instruct and extract- to convert. His translations were intent on creating citizens that would industrialize and Americanize Brazil, increase its competitiveness, improve its educational system, and popularize the circulation of books. His extractive translations were tools to bring renewed possibilities to a country he considered stuck in backwardness.

Lobato's version of Peter Pan, for example, stages translation as a teaching opportunity, or rather, a homily. As in a mass, the scene of translation is very structured (it takes place every day at the same time, and everybody listens while the translator, dona Benta, officiates.) When everybody is sitting, dona Benta (the grandmother) improvises a rendering of the story to an audience in which, among others, there is a boy (Pedrinho) and a human-toy (Emília). At one point, while dona Benta is explaining where Wendy and her siblings live, Pedrinho interrupts her:

-Esses meninos ocupavam a mesma nursery numa linda casa de Londres.

—Nursery? - repetiu Pedrinho. — Que vem a ser isso?

- Nursery (pronuncia-se nârseri) quer dizer em inglês quarto de crianças. Aqui no Brasil quarto de criança é um quarto como outro qualquer e por isso não tem nome especial. Mas na Inglaterra é diferente. São uma beleza os quartos das crianças lá, com pinturas 
engraçadas rodeando as paredes, todos cheios de móveis especiais, e de quanto brinquedo existe.

—Boi de chuchu, tem? - indagou Emília.

- Talvez não tenha, porque boi de chuchu é brinquedo de meninos da roça e Londres é uma grande cidade, a maior do mundo. As crianças inglesas são muito mimadas e têm os brinquedos que querem. Os brinquedos ingleses são dos melhores. (23)

This does not look like a politically charged text. But it was because of passages like this that, Milton explains, the "Department of Social and Political Order (DEOPS) apprehended and confiscated all the copies of Monteiro Lobato's Peter Pan that it could find in the state of São Paulo" (205). This version of Barrie's novel, it was argued, "molded the spirit of children into a mentality that would destroy nationalism" (Milton 205). Against the Estado Novo, Monteiro Lobato planted a cross - four centuries after Cabral and with a different kind of inbetween - to instill the need for "progress."

Projective and extractive translations can be seen in other literary events. Looked at from translation, we can sense an affinity between Modernismo's primitivistic tendencies and Alencar's Romantic Indianism. For, is not the Manifesto antropófago itself but a series of claims in which a voice translates as if it knew the most profound truths of indigenous cultures, projecting onto the Other the needs of a modern culture? After all, both Alencar and Oswald de Andrade attempted to bridge universalism and particularism, one with Chateaubriand in mind, the other by ironically quoting and thus translating Shakespeare ("Tupi or not tupi.") And, if Alencar imagined words emanating from a non-existent original, the anthropophagic "law" is also expressed by an "I" that puts in the native's mouth a universal "human law": "Só me interessa o que não é meu. Lei do homem. Lei do antropófago" (226).

Extractive translations, of course, can be identified easily in the Jesuit mission emblematized by the work of Father Anchieta (or entire projects like the "Língua Geral" that sought to promote Christianity in three steps-first to learn the local language, then to standardized it, then to translate into it - that we can correlate with mercantile terms: find, homogenize, and exploit the resource). But the extractive impulse can also be found in translations of certain kinds of French novels that were meant to "educate" young women in the nineteenth and 
twentieth century, such as those in popular collections like "Biblioteca das moças," that were designed to expose students to "models" of proper behavior. ${ }^{4}$ In sum, projective and extractive translations align with several cultural projects in Brazilian history. And this is logical, because they take place in situations of dominance and power asymmetries, when the Other (be it the "local material" or the "native reader") is in some form exploited or disciplined through translation. Contrary to the projective and extractive, the interpretive regime materializes, as we shall see, when the appropriative uses of translation are thwarted.

\section{The Interpretive Regime in Twenty-First Century Fiction}

When an unknown language is indistinguishable from breaking waves and wailing sounds, when signifiers are not recognized as such or seem radically detached from signifieds, emotions run high. Roland Barthes experienced this indeterminacy with relief, even jouissance, Octavio Paz with discomfort, even anger. ${ }^{5}$ In Caminha's account, the opacity of signifiers and the waves that break on the shore belong in principle in the same category: they are both obstacles to the imperial project.

But these moments of encounter with the unintelligible Other that punctuate the narrative with interruptions or delays also provoke emotional uneasiness. In one dramatic moment, untranslatability comes about, seemingly, as a sudden interdiction:

[...] aly amdauam antreles tres ou quatro moças bem moças e bem jentijs com cabelos mujto pretos conprjdos pelas espadoas e suas vergonhas tam altas e tã çaradinhas e tam limpas das cabeleiras que de as nos mujto bem olharmos nõ tijnhamos nhuu[m]a vergonha. aly por emtam nom ouue

\footnotetext{
${ }^{4}$ See Santos Cunha.

${ }^{5}$ Barthes writes: "The murmuring mass of an unknown language constitutes a delicious protection, envelops the foreigner (provided the country is not hostile to him) in an auditory film which halts at his ears all the alienations of the mother tongue: the regional and social origins of whoever is speaking, his degree of culture, of intelligence, of taste, the image by which he constitutes himself as a person and which he asks you to recognize. Hence, in foreign countries, what a respite!" (9). Paz expresses radically opposite feelings when he points out that "the awe, the anger, the horror, the puzzled perplexity we feel when facing the sounds of a language we don't know, soon turns into doubt about the language we speak. Language loses its universality and reveals itself as a plurality of languages, all of them mutually strange and unintelligible" (7).
} 
mais fala ne[m] emtendimento cõ eles por aberberja deles seer ta manha que se nom emtendia nem ouuja njnge[m]. (f. $4^{\text {r }}$ )

The "barbarity" of the undecipherable language halts here an intense, sexually charged scrutiny of native women. When the contours of the girls have been perfectly explored and perhaps another type of exploration is imminent, the untranslatable barbaric language - conveniently, it seems - prevents "mais fala ne[m] entendimento" or, perhaps, more intercourse.

It is this kind of intimate after-effect of facing a language that seems undecipherable that reappears in contemporary Brazilian fiction, in novels such as Buarque's Budapeste and João Gilberto Noll's Berkeley em Bellagio and Lorde. Languages, in these fictions, become imbricated with identities. The materiality of languages, with bodies. And the desire to translate, with physical desire for the Other. The interpretive regime in Caminha's letter thus resurfaces. Although, of course, circumstances have changed, and so have the heroes. The protagonists in Buarque's and Noll's novels are, far from official escrivãos on an exploratory mission, more like twenty-first century versions of degradados: baffled beings - the three of them, significantly, writers - who are brought to a distant land and somewhat made to stay for reasons beyond their knowledge or control. As if the anxieties of the first globalization represented by Caminha have come back, but this time with a change of perspective, at another speed, and in a very different chronotope - not the shore, as in the interpretive regime in Caminha's time, but the airport: Budapeste starts with an unexpected layover in Hungary; Lorde, at Heathrow airport, in London; Berkeley em Bellagio with an oneiric walk through a US university campus. The protagonists in these novels do not travel, prepare their trip, or even anticipate what will take place-they simply land, or are somewhat thrown into contact with the foreign. Their new lives are uncertain, precarious - without a telos or clear motivation. In this sense, too, they are reminiscent of those obscure, agency-deprived exiles on Cabral's ship.

The Carta does not say much about the degradados: we learn about them briefly and in the third person. We are left to imagine what would happen to them when the ships leave them behind. Buarque's and Noll's narratives, in turn, focalize their novels on how the protagonists have to make their way haphazardly through languages they don't understand in distant lands. These beings have to 
face the experience of the foreign with little to no resources, and at a very intimate level: as they desire and fear a new language and culture, their very identities flow and change while they lose touch with their native tongue.

In Budapeste, the ghostwriter Jose Costa lands in Hungary due to an accidental layover and is suddenly thrown into contact with a confusing city (a city that changes color every fifty pages in the novel) where locals speak, "segundo as más línguas, a única língua que o diabo respeita" (6). Jose Costa does not understand Hungarian words because he cannot tell them apart, let alone translate them into anything intelligible. Yet he is enthralled by the sounds, the taste, the intonations of this language alien to him. Following this siren song, he abandons his old life in Rio to stay in Budapest, where he becomes a starving homeless man whose only support is his Hungarian teacher and lover, Kriska. The materiality of the language becomes conflated with her body. The narratorprotagonist points out: "Sem a mínima noção do aspecto, da estructura, do Corpo mesmo das palabras, eu nao tinha como saber onde cada palabra comecava ou até onde ia. Era impossível destacar uma palabra da outra, seria como pretender cortar um rio a faca" (8). And later: "De tao branca a sua pele, era quase impossivel discernir os contornos do corpo no lençol de linho" (68). The unrecognizable contours of the desired flowing words parallel the impossibly white body of Kriska.

As Costa enters the mystery of the Hungarian language, Kriska starts defining who he is. Costa's identity suffers a transformation, as his very name gets translated. He is no longer José Costa but instead Zsoze Kósta, or both, as the novel progresses: "Falou Zsoze Kósta... Zsoze Kósta... me olhando de alto a baixo, como se meu nome fosse um traje inadequado. Deixei que falasse Zsoze Kósta até se habituar e não corrigi sua pronúncia, muito menos caçoei de Kriska, antes, dei-lhe razão e passei a me conhecer por Zsoze Kósta em Budapeste" (6263, my emphasis). He is known to others as Kósta, and ambiguously also knows himself as Kósta too, but who is the "he" that knows? Living in the interstice between two identities, Costa-Kósta wanders in the hyphen produced by translation. 
Contemporaneously, Noll wrote two novels - which can be described as "autofictions"- about intimate encounters with foreign languages and bodies. ${ }^{6}$ In Berkeley em Bellagio, a Brazilian writer drifts purposelessly from Brazil to the US to Italy. The narrator-protagonist points out the presence of "palavras sem semântica [que] funcionavan para mim como um mantra, e como tal era hipnótico, me levava a um estado de indeterminação" (54). Confronted by the confusion of being away from the Portuguese language, the writer loses his former linguistic ability and suddenly starts speaking in English. His name, like Jose Costa's, gets translated as he is baptized by a foreign colleague who at some point tells him where to go: "você ali, você, meu caro amigo brasileiro, a repetir pela milésima vez para que eu pegasse para sempre: Joao, Joao" (63). He is now Joao, no longer João.

A year later (2004), Noll published another novel about a Brazilian experiencing the foreign, and with it an identity transformation. In Lorde, "o inglês" (an Englishman and/or the English language) arranges a visit to England that the Brazilian writer cannot refuse. As soon as he lands he starts flowing aimlessly, suffers amnesia, becomes comatose. He constantly tries out identities: "eu era um dandî"; "eu era o estúpido da cidadela global"; "eu era um soldado ocasionalmente ferido"; "eu era Apis" $(29,37,40)$. The novel ends with a sexual encounter where this disoriented, flowing life acquires the body of another, and another's name: "vem George, repeti sem saber se chamava por alguém ainda desorientado no ato de me traduzir com seu próprio corpo" (110, my emphasis). The identities of the protagonists, even their names, change as they get translated into other languages. Significantly, the plots give no clear reasons as to why these characters undergo these experiences as castaways in distant shores (Budapest, Liverpool, Berkeley, Bellagio). ${ }^{7}$ What seems clear is that the decision is not theirs.

As we first saw in Caminha's letter, the materiality of language emerges in these novels in moments of intense personal contact with the Other. It is as if, emptied out of the possibility of meaning, the desire to translate produces an

\footnotetext{
${ }^{6}$ For a study on autofiction in contemporary Brazilian narratives, which from the early nineties until the mid-aughts was a widespread phenomenon in Brazilian letters, see Klinger.

${ }^{7}$ It is a trend in contemporary fiction to render character motivation opaque, inscrutable, or nonexistent. In Buarque's and Noll's novels, the forces that throw them into encounters with the foreign are unclear. Manzoni argues that errancy is the fundamental topos of contemporary Latin American fiction.
} 
adjacent kind of material desire: that of the foreign body. Indeed, in Buarque's and Noll's novels language is physical. In Budapeste, as we saw, the naked white body of the Hungarian woman evokes the contour-less body of the Hungarian language. Costa drinks Kriska's milk, and the Magyar language is said to modify his senses (dictating what can be tasted, heard, and seen) $(46,10,64,160)$. Noll's Berkeley em Bellagio also imbricates language and sex: "o escritor [...] acabou de se comunicar com o meu repentino inglês fluente, tão fluente que de seu corpo deslizou o sêmen que não pôde seguir as conveniências as se arremessar sem seu dono mesmo se dar conta" (61). And in Lorde, the main character feels how a language takes over his body: "falo o que me vem à boca, ocupo em versículos meus lábios, meus dentes, gengivas" (51).

What to make of these protagonists, Brazilian writers who lose their language and identity as they undergo the experience of the foreign? How to explain that the result of being abroad is not cosmopolitan enlightenment but homelessness? Through these incarnations of language, the novelists seem to explore the irresistible desire and disquieting possible outcomes of adopting another language and losing an identity "in Portuguese." Because language is material and bound to the body, changing into a new language is a radical and fundamental decision: according to these fictions, two languages cannot be inhabited simultaneously. And that seems to be, ultimately, the danger behind these experiences: "[P]arecia só existir aquilo, uma casa desconhecida que teria de ocupar, uma língua nova, a língua velha que tão cedo assim já me parecia faltar em sua intimidade," we read in Lorde (19). Costa, in Budapeste, wonders if it is perhaps necessary to forget "a própria língua em que foram ditas [as palavras], como nos mudam da casa que nos lembra um morto" (121). In Berkeley em Bellagio, the narrator explains: "[E]u já pensava em inglês, se perguntassem de onde tinha vindo essa repentina fluência nessa língua, um cínico que me ouvia cá dentro responderia que eu fora iluminado durante o meu longo, longo sono pelo Espírito Santo - Holy Ghost, é lógico, tudo em inglês" (56).

Gonzalo Aguilar has argued that of all contemporary Latin American literatures, Brazil's is the most post-nationalist, most "attentive to the effects of globalization." One of these effects, as it appears in Buarque's and Noll's novels, is the exposure to unknown foreign languages that produces an irresistible desire to engage the Other and its language at the most intimate levels: Jose Costa desires Kriska and her language; the protagonist in Lorde desires English and the 
Englishman. That seemed to have been also the case with Caminha, when his shameless visual exploration of the natives' bodies was interrupted.

\section{The Case for Translation Regimes in Literary History}

Most Brazilian literary histories are structured to account for the emergence of an autonomous literature-from "colonial" to "national" (José Veríssimo), from simple to developed (Romero), from having a less to evidencing a more consolidated national conscience and style (Coutinho), from "mirrorlike" and dependent to "grown-up" and independent (Erico Veríssimo, Carvalho, Bosi), from non-existing to identifiable (Oliveira Lima) or forming a "system" (Candido), and more recently, from national to transnational. The consistency of this emplotment, as well as the emplotment itself, are unsurprising: on the one hand, literary histories are often built upon other literary histories, so they often repeat initial paradigms; on the other, as David Perkins puts it, "the possible plots of narrative literary history can be reduced to three: rise, decline, and rise and decline" (39). ${ }^{8}$ Complementing historians that have accounted narratively for the "rise" of a national (and now transnational) literature, there are critics who have thought conceptually about the specificity of Latin American culture in general, and Brazilian in particular. Their most prominent metaphors are topological, as they often speak of people, ideas, languages, and knowledges that go back and forth, clash, compromise, move - think for example of Fernando Ortiz's "counterpoint," Angel Rama's "transculturation," Mary Pratt's "contact zone," and in the Brazilian case Silviano Santiago's "um entre-lugar", Roberto Schwarz's "idéias fora de lugar," Haroldo de Campos's "excentricidade," and Flora Süssekind's "sensação de não estar de todo."

\footnotetext{
${ }^{8}$ Erico Veríssimo's opening lecture on Brazilian literature is paradigmatic of the evolutionary narrative: "During almost four hundred years the intellectual life of my country kept a mirrorlike quality: it reflected the literary and artistic fashions of Europe, first through Portugal and afterward directly from Paris. But after the first two decades of the twentieth century we started a literary life of our own - of course not totally free from alien influence, because no literature is completely independent, but at least a literature concerned with Brazilian social and moral problems and speaking a Brazilian language" (2, my emphases). Weber notes that most other historians have repeated this structure. Recently, critics have focused on notions of alterity and spatiality, revealing an increased interest in transnationalism and fluidity beyond the nation. See, for example, Chiarelli and Oliverira Neto; Goulart Almeida; Dalcastagne and Vasconcelos Leal; Dalcastagne and Azevedo.
} 
The map of Brazilian literary historiography is, then, demarcated syntagmatically by narratives that follow a discernible plot, and paradigmatically by conceptual frameworks that propose a stable impetus. This arrangement has advantages, perhaps none more important than enabling explanations of change or continuity. But it also has disadvantages. On the one hand, the narrative configuration usually situates literary events along a periodization that presupposes, to cohere, an evolutionary logic of causality. On the other, conceptual categories suggest that literary events are manifestations of a single operation (by a "cultural identity") that deals with a problem that repeats iself over time. This is particularly evident in Haroldo de Campos's and Alejo Carpentier's understanding of "the Baroque" as the distinctively Latin American literary mode. ${ }^{9}$ In short, since narratives are framed to show $a$ sequence and concepts are posited to identify $a$ master cultural gesture, they are both designed to disregard multiplicity.

There is something undoubtedly Hegelian and monolithic about frameworks that look for evidence of "development" (towards an "identity") or that identify a single operation (a "Spirit") that evolves into more fruitful answers to a persistent problem. Thinking in terms of regimes, on the contrary, enables multiplicity. By considering Noll's and Buarque's fictions as potential participants in a historical translation regime-rather than representatives of "contemporary transnational narratives"-we could see how they revisit Caminha's very old problem of how to face (conquer, embrace, ignore, surrender to?) unknown languages in a globalizing world. Translation regimes enable such speculations and potential comparisons: they highlight unseen discontinuities, obsessions, as well as unexpected, awkward, or even jarring affinities. In an age of highly specialized knowledge, reviving the historiographical debate may prove to be-like translation itself-a productive step towards unforeseen encounters.

\footnotetext{
${ }^{9}$ For Campos, Gregório de Matos (1633-1695), Odorico Mendes (1799-1864), Andrade (18901954), and even the tropicalistas of the 1960s are avatars of a single subject, since they all irreverently adapt and adopt different voices and languages in their versions of cultural anthropophagy. This argument pushes forcefully against Candido's "Romantic" and teleological framework. Carpentier holds a similar place in Spanish-American letters, arguing that the Baroque is historically the birth sign of Latin America and conceptually its "spiritual constant." For his part, Silviano Santiago focuses on defining the characteristics of a rebellious, independent, and strategic subject who challenges cultural dependence.
} 


\section{Works Cited}

Aguilar, Gonzalo. “El mapa del hormiguero”. Página/12. 16 Nov. 2006, www.pagina12.com.ar/diario/suplementos/espectaculos/subnotas/45011554-2006-11-16.html.

Alencar, José de. "Carta ao Dr. Jaguaribe." Obra completa, vol. III. Aguilar, 1959. pp. 305-20.

—. "Iracema." Obra completa, vol. III, Aguilar, 1959. pp. 223-319.

Andrade, José Oswald de Souza. "Manifesto antropófago." Vanguarda européia e modernismo brasileiro: apresentação crítica dos principais manifestos, prefácios e conferências vanguardistas, de 1875 até hoje, edited by Gilberto M. Teles, Vozes, 2009. pp. 226-32.

Barrie, James Matthew. Peter Pan, translated by José Monteiro Lobato, 15th ed., Brasiliense, 1971.

Barthes, Roland. Empire of Signs, translated by Richard Howard, Hill and Wang, 1982.

Bosi, Alfredo. História concisa da literatura brasileira. Cultrix, 1997.

Buarque, Chico. Budapeste. Companhia das Letras, 2003.

Candido, Antonio. Formação da literatura brasileira, 2 vols., Itatiaia,1997.

Carvalho, Ronald. Pequena história da literatura brasileira. Itatiaia, 1984.

Caminha, Pêro Vaz de. Carta a el-rei D. Manuel sobre o achamento do Brasil, Biblioteca Nacional de Portugal, purl.pt/162/1/brasil/obras/carta_pvcaminha/index.html.

Campos, Haroldo de. O sequestro do Barroco na Formação da literatura brasileira: o caso Gregório de Mattos. Fundação Casa de Jorge Amado, 1989.

—. "The Ex-Centric's Viewpoint: Tradition, Transcreation, Transculturation." A Dialogue with the Brazilian Poet, edited and translated by K. David Jackson, Oxford UP, 2005, pp. 3-13.

Carneiro, Sarissa. "Aproximaciones a la carta de Pero Vaz de Caminha al rey D. Manuel sobre el descubrimiento de Brasil." Revista chilena de literatura, vol. 62, 2003, pp. 105-18.

Carpentier, Alejo. "Lo barroco y lo real maravilloso." Los pasos recobrados, Ayacucho, 2003, pp. 68-87. 
Castello, José Aderaldo: A literatura brasileira-origens e unidade (1500-1960), 2 vols., U de São Paulo, 1999.

—. A polêmica sobre A confederação dos tamoinos. U de São Paulo, 1953.

Chiarelli, Stefania and Godofredo de Oliverira Neto. Falando com estranhos: $o$ estrangeiro e a literatura brasileira. 7 Letras, 2016.

Cortesão, Jaime. A carta de Pêro Vaz de Caminha. Livros de Portugal, 1943.

Coutinho, Afrânio. O conceito da literatura brasileira, Acadêmica, 1960.

Dalcastagne, Regina, and Virginia Maria Vasconcelos Leal. Espaço e gênero na literatura brasileira contemporânea. Zouk, 2015.

-, and Luciene Azevedo. Espaços possíveis na literatura brasileira contemporânea. Zouk, 2015.

Edelweiss, Frederico G. José de Alencar: o tupinista segundo as notas ao romance Iracema. U Federal da Bahia, 1979.

Freyre, Gilberto. Como e por que sou e não sou sociólogo. U de Brasília, 1968.

Gadamer, Hans-Georg. Truth and Method, translated by Joel Weinsheimer and Donald G. Marshall, Continuum, 2004.

Goulart Almeida, Sandra Regina. Cartografias contemporâneas: espaço, corpo, escrita, 7 Letras, 2015.

Johnson, Randall. "Tupy or not Tupy: Cannibalism and Nationalism in Contemporary Brazilian Literature." Modern Latin American Fiction: A Survey, edited by John King, Faber and Faber, 1987, pp. 41-59.

Klinger, Diana. Escritas de si, escritas do outro: o retorno do autor e a virada etnográfica, 7 Letras, 2007.

Kuhn, Thomas. The Structure of Scientific Revolutions. U of Chicago P, 1962.

Manzoni, Celina. Errancia y escritura en la literatura latinoamericana contemporánea, RCA, 2009.

Martins, Wilson. "Formação e desenvolvimento da lingua nacional." A literatura no Brasil, vol. 1, edited by Afrânio Coutinho, Global, 1997, pp. 220-47.

Monteiro Lobato, José Bento, translator. Peter Pan, by J. M. Barrie, 15th ed., Brasiliense, 1971.

Milton, John. "The Resistant Political Translations of Monteiro Lobato". Translation, Resistance, Activism, edited by Maria Tymoczko, U of Massachusetts P, 2010, pp. 190-210.

Noll, João Gilberto. Berkeley em Bellagio, Objetiva, 2002.

—. Lorde. Francis, 2004. 
Oliveira Lima, Manoel de. Aspectos da literatura colonial brasileira. Francisco Alves, 1984.

Ortega, Francisco. "Excessive Friendships: Face-to-Face and Play in Caminha's 'Letter to the King' (1500)." Chasqui, vol. 34, no. 1, 2005, pp. 7-41.

Ortiz, Fernando. Contrapunteo cubano del tabaco y el azúcar, Cátedra, 2002.

Paz, Octavio. Traducción: literatura y literalidad. Tusquets, 1971.

Perkins, David. Is Literary History Possible? Johns Hopkins UP, 1992.

Rama, Angel. Transculturación narrativa en América Latina. Siglo XXI, 1982.

Pratt, Mary. Imperial Eyes: Travel Writing and Transculturation, Routledge, 1992.

Romero, Sílvio. Evolução da literatura brasileira: vista synthetica. Campanha, 1905.

Santiago, Silvano. "O entre-lugar no discurso latino-americano." Uma literatura nos trópicos. Perspectiva, 1978, pp. 11-28.

Santos Cunha, Maria Teresa. Armadilhas da sedução. os romances de M. Delly. Autêntica, 1999.

Schwarz, Roberto. As ideias fora de lugar. Penguin-Companhia das letras, 2014.

Süssekind, Flora. O Brasil não é longe daqui: o narrador, a viagem. Companhia das Letras, 1990.

Veríssimo, Erico. Brazilian Literature: An Outline. Praeger, 1970.

Veríssimo, José: História da literatura brasileira. Record, 1998.

Voigt, Lisa. "'Por andarmos todos casy mesturados': The Politics of Intermingling in Caminha's 'Carta' and Colonial American Anthologies." Early American Literature, vol. 40, no. 3, 2005, pp. 407-39.

Walker, Keith Louis. "Pêro Vaz de Caminha: para fijar la mirada en el corazón de tinieblas del nuevo mundo." Revista de Crítica Literaria Latinoamericana, no. 60, 2004. pp. 43-55.

Weber, João Hernesto. A nação e o paraíso: a construção da nacionalidade na historiografia literária brasileira. U Federal de Santa Catarina, 1997.

Williams, Jerry. "Pêro Vaz de Caminha: The Voice of the Luso-Brazilian Chronicle." Luso-Brazilian Review, vol. 28, no. 2, 1991, pp. 59-72. 